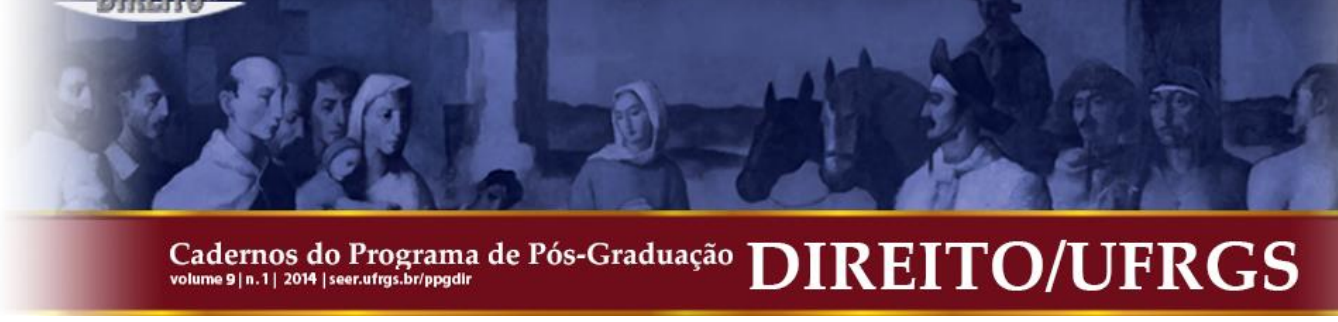

\title{
MOVIMENTOS SOCIAIS, DIREITO DE RESISTÊNCIA E NORMATIVIDADE: A RESISTÊNCIA CIVIL EM CONFLITO COM A LEI E A ORDEM NOS MOVIMENTOS DE PROTESTO, NO ÂMBITO DO ESTADO CONSTITUCIONAL
}

\author{
SOCIAL MOVEMENTS, RIGHT OF RESISTANCE, AND NORMATIVITY: CIVIL RESISTANCE IN
}

CONFLICT WITH LAW AND ORDER IN THE DEMONSTRATION MOVEMENTS WITHIN THE

CONSTITUTIONAL STATE

Fernando Antonio Alves*

\begin{abstract}
RESUMO: Este artigo tem a proposta de discutir os efeitos políticos e jurídicos das manifestações populares ocorridas a partir de junho de 2013, no Brasil, protagonizadas por diversos atores, dentre eles, integrantes de movimentos sociais, como o movimento conhecido como Passe Livre. Essas manifestações foram responsáveis por revelar uma gama de grupos e reivindicações, que reacendem o debate sobre a atualidade da luta de classes e a força política da mobilização popular. Junto a isso, entende-se que uma abordagem sobre o fenômeno da resistência civil, em seus aspectos políticos e jurídicos, torna-se bem útil a fim de analisar até que ponto determinadas mobilizações sociais por meio dos meios de comunicação alternativos podem revelar uma pluralidade normativa diversa do monismo normativo encontrado no Direito oficial estatal, mormente com o emprego da teoria dos sistemas sociais autopoiéticos e a concepção de Constituição enquanto acoplamento entre o sistema político e o sistema jurídico, além de vislumbrar o surgimento de redes de mobilização e protesto em distintas comunidades. Tal estudo pode revelar até que ponto os fenômenos de revolta social e proposição de discurso revolucionário ainda podem ter eco nas reivindicações sociais de sociedades de modernidade tardia, tais como as reivindicações sociais do exemplo brasileiro.
\end{abstract}

PALAVRAS-CHAVE: Movimentos sociais; Direito de Protesto; Resistência Civil; Direitos Fundamentais.
ABSTRACT: This paper has proposed to discuss the political and legal effects of popular demonstrations that took place from June 2013 on in Brazil, leaded by several actors, among them members of social movements such as the movement called Free Fare Movement. These demonstrations were responsible for revealing a range of groups and claims that rekindle the debate about the relevance of class struggle and the political power of popular mobilization. Along with this, it is understood that an approach to the phenomenon of civil resistance, in its political and legal aspects, becomes very useful in order to analyze the extent to which certain social mobilizations through alternative media may reveal a normative plurality diverse from the normative monism found in the official state law, especially with the use of the theory of autopoietic social systems and the conception of Constitution as a coupling between the political system and the legal system, in addition to the perception of the emergence of networks of mobilization and demonstration in distinct communities. This study may reveal the extent to which the phenomena of social revolt and enunciation of revolutionary discourse can still be reflected in the social demands of late modernity societies, such as the social demands of the Brazilian example.

KEYWORDS: Social Movements; Right to Protest; Right to Demonstrate; Civil Resistance; Fundamental Rights.

SUMÁRIO: Introdução. 1. Desobediência civil e direito de resistência no marco do Estado moderno: fundamentos teórico-filosóficos do sistema político moderno, dentro da ordem constitucional estabelecida e a consequente repressão estatal pelo discurso da manutenção da ordem diante de sua iminente violação. 2. A criminalização dos protestos no Brasil por meio da lei 12.850 de 2013: seriam os black blocs os novos inimigos do Estado? 3. Sistema jurídico fundado no Direito oficial e o Direito dos diversos subsistemas sociais, na tensão entre um direito emancipatório e um direito regulatório. 4. Normatividade policontextural na atuação dos movimentos sociais. Considerações finais. Referências.

\section{INTRODUÇÃO}

Junho de 2013 parece ter sido um marco divisório na história recente dos movimentos sociais no Brasil, após a primeira década do século XXI. As manifestações convocadas em São Paulo pelo Movimento Passe Livre (MPL) foram responsáveis por levar um impressionante contingente de pessoas para as ruas. Estudantes e jovens de diversos grupos

\footnotetext{
* Faculdade Maurício de Nassau - RN.
} 


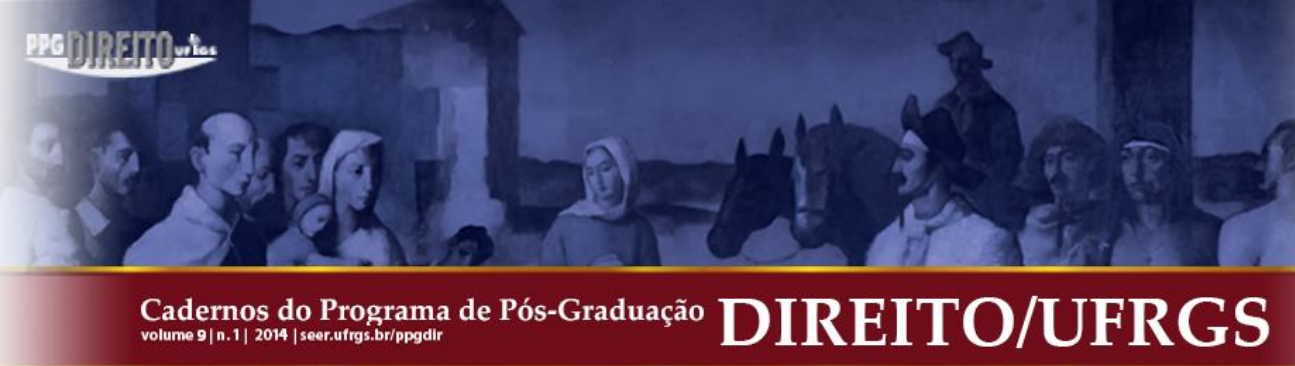

Nova Holanda, no Complexo da Maré, Zona Norte do Rio de Janeiro, em 25 de junho, quando, sob o pretexto de realizar uma operação policial para prender traficantes, policiais militares do Batalhão de Operações Especiais (BOPE) foram acusados de ser os responsáveis da morte de treze pessoas e nove feridos. ${ }^{3} \mathrm{Na}$ paisagem carioca, enquanto os manifestantes ocupavam as ruas e eram reprimidos duramente com bombas de gás pela polícia, na favela, como compondo uma triste rotina, cidadãos pobres, moradores da periferia, eram mais uma vez vítimas de balas disparadas nos conflitos resultantes das ações precipitadas da polícia, no seu suposto conflito com o tráfico de drogas e a criminalidade em geral.

Nesse contexto de mobilização social, os movimentos que eclodiram no Brasil em junho de 2013 não se restringiram a uma massa multifacetada e plural que tomou as ruas da urbe, exigindo reivindicações que vinham desde a inexistência de cobrança de pagamento de passagens em transportes públicos para desempregados e estudantes, até tradicionais petições de melhorias nos serviços públicos em geral, como saúde e educação. Nesse sentido, o papel das redes sociais por meio de comunicações virtuais via internet, também não foi menos relevante, uma vez que novas comunidades de informação surgiram, e coletivos virtuais foram criados para desenvolver uma nova forma de jornalismo alternativo, denominados de “Mídia Ninja!" responsáveis por algumas das impressionantes imagens desses protestos, como também testemunharam a ação policial, numa intervenção estatal que, em alguns casos, pecou pelo excesso.

Mas o que levou milhares de brasileiros a questionar o Estado, sua autoridade e seu sistema político, se o país vive um ambiente de normalidade democrática, nunca visto em sua história de controle político oligárquico, ditadura exercida por um chefe político carismático e populista ou pelo autoritarismo de governantes militares? Desde a "Passeata dos Cem Mil", na década de sessenta do século passado, e desde o movimento "Fora Collor" na década de noventa do século passado, o Brasil não via manifestações de rua tão intensas como as que aconteceram a partir de junho de 2013. Na iminência de dois grandes eventos esportivos de repercussão mundial, como a Copa das Confederações, em 2013, e a Copa do Mundo, em 2014, o país parece ter aparecido para a mídia mundial não apenas como a região sede destas duas grandiosas competições futebolísticas, que atraem milhões de investimentos, publicidade e turismo, mas também como uma nação conturbada por uma série de contradições internas e conflitos de classe, que levaram uma multifacetada multidão de indivíduos com seus

\footnotetext{
${ }^{3}$ ALLEGRINI, Gabriela, Op. Cit., p. 28.
} 


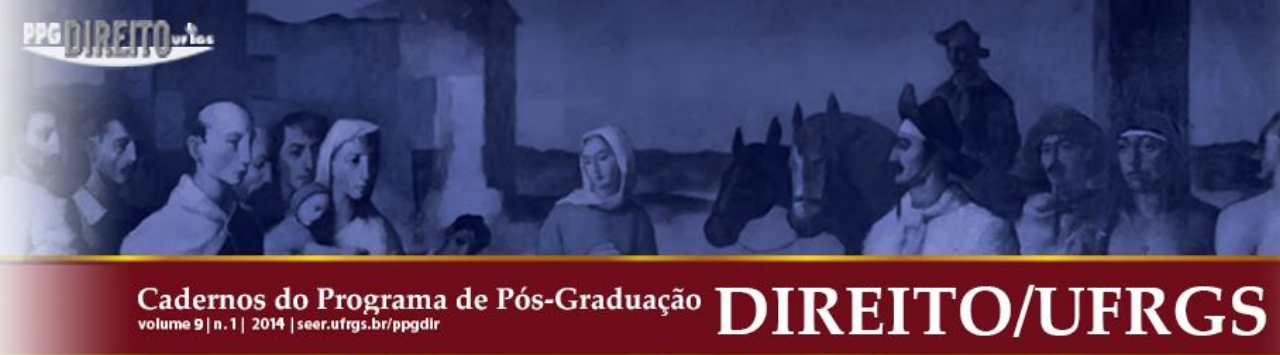

respectivos interesses às ruas, cobrando uma agenda comum voltada para temas de políticas públicas, tais como saúde, segurança, educação e moralidade pública. Nesse sentido, a reação dos aparelhos de Estado, em especial de seus efetivos policiais, parece não ter sido muito distante do modelo de intervenção previsto no período da ditadura militar no Brasil. Mais uma vez protestos foram reprimidos com violência, por vezes desmedida, e, em alguns casos, quando não foi empregada a força excessiva não foi empregada força nenhuma, o que resultou também num retrato de caos, destruição e danificação do patrimônio público, mediante praças, estabelecimentos e edificações públicas danificadas. Qual o limite, portanto, para o exercício constitucional do protesto, garantindo-se a livre expressão de pensamento e a liberdade de reunião, e qual a limitação à ação destrutiva de coletivos que se dedicam, especificamente, a prática de delitos e não à reivindicação de direitos? Talvez uma análise mais pormenorizada, acerca do conceito de desobediência civil e sua repercussão constitucional, possa vir a auxiliar e esclarecer alguns pontos que parecem, inicialmente, obscuros para os estudiosos do Direito e da Ciência Política.

\section{DESOBEDIÊNCIA CIVIL E DIREITO DE RESISTÊNCIA NO MARCO DO} ESTADO MODERNO: FUNDAMENTOS TEÓRICO-FILOSÓFICOS DO SISTEMA POLÍTICO MODERNO, DENTRO DA ORDEM CONSTITUCIONAL ESTABELECIDA E A CONSEQUENTE REPRESSÃO ESTATAL PELO DISCURSO DA MANUTENÇÃO DA ORDEM DIANTE DE SUA IMINENTE VIOLAÇÃO

O conceito de desobediência civil e o exercício do direito de protesto encontram seu respaldo histórico e fundamento no conceito de resistência. Por resistência pode-se entender todo movimento popular de questionamento do poder, traduzindo-se num direito político, por excelência, que se desdobra no ordenamento jurídico de um povo a partir do reconhecimento ou não de direitos, que podem levar tanto a uma regulação de condutas por meio do Direito civil, como à repressão dessas condutas por um Direito penal. Nesse sentido, os contornos da resistência e a reação estatal diante de formas de manifestação popular a questionar a ordem estabelecida é que irão diferenciar modelos democráticos ou autoritários de Estado. A resistência pode tanto evoluir para a emancipação democrática, em torno de processos políticos revolucionários ou reformistas, como pode também chegar ao ponto em que se estará diante de uma plena repressão estatal, responsável por consolidar o modelo autoritário, a 


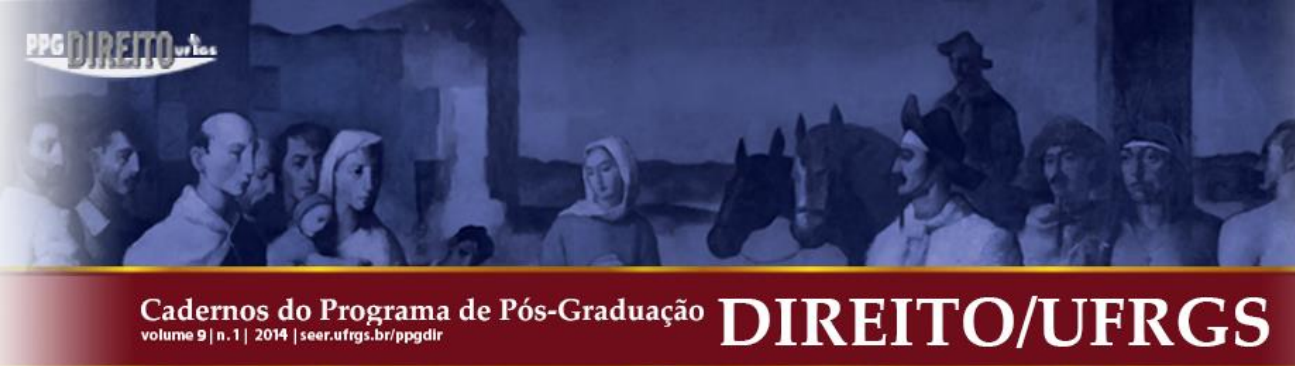

reprimir e até mesmo aniquilar com a resistência, como se dá nos golpes de Estado. Importante salientar que em diferentes regimes políticos, em sociedades mais democráticas ou fustigadas pelo autoritarismo, a resistência sempre se encontrará presente, em maior ou menor grau.

Segundo Buzanello, resistência funda-se num espírito libertário que adota ações pragmáticas inibidoras dos abusos de poder em caráter preventivo e visa também restabelecer uma ordem democrática violada, em seu caráter repressivo. ${ }^{4}$ A resistência, como é conhecida hoje, por meio de manifestações que, não raro terminam em conflitos com agentes do Estado, tem seus fundamentos históricos na filosofia política desenvolvida na modernidade a partir de Hobbes, passando pelo pensamento de John Locke, revelando um claro contraste entre conservadorismo e liberalismo na filosofia política e teoria do Estado. Tal conflito filosófico irá também repercutir na tensão entre o Direito enquanto instrumento de regulação ou de emancipação social e na contraposição entre a manutenção da ordem por um poder político estabelecido, e sua consequente violação por meio da mobilização popular, nos termos da resistência a uma ordem estabelecida, porém questionada.

Tanto em Hobbes como em Locke, nos primórdios do pensamento político moderno, pode-se perceber como o tema da resistência ganha atenção especial, tornando-se um dos conceitos fundamentais à ação política, como também um fator gerador de direitos, reconhecidos constitucionalmente em diferentes períodos históricos. Em Hobbes, no século XVII, o tema da resistência aparece contingencialmente, ao tratar da liberdade dos súditos. ${ }^{5} \mathrm{~A}$ liberdade do súdito é a liberdade autorizada pelo Estado; ou seja, é a liberdade do soberano. A liberdade estatal seguida e usufruída pelos súditos está assentada nas leis civis, resultantes de um pacto coletivo, um acordo social em que os indivíduos saem de um destrutivo estado de natureza onde prevalece a sua liberdade individual (assim como os conflitos dela resultantes) e renunciam a tal liberdade, em prol da liberdade assegurada pelo Estado com suas leis. Entretanto, não se dá uma adesão cega do povo ao soberano no momento do pacto, quando se renuncia a uma liberdade natural, num novo estado de submissão e obediência; pois Hobbes asseverava que todo súdito teria preservada a liberdade de gerir como bem entendesse seus interesses, relacionados com todos aqueles direitos que não pudessem ser transferidos por meio de um pacto.

\footnotetext{
${ }^{4}$ BUZANELLO, José Carlos. Direito de resistência constitucional. Rio de Janeiro: Lumen Juris, 2006, p. XVIII.

${ }^{5}$ HOBBES, Thomas. O Leviatã. Tradução de João Paulo Monteiro e Maria Beatriz Nizza da Silva. São Paulo Abril Cultural, 1979, p. 130.
} 


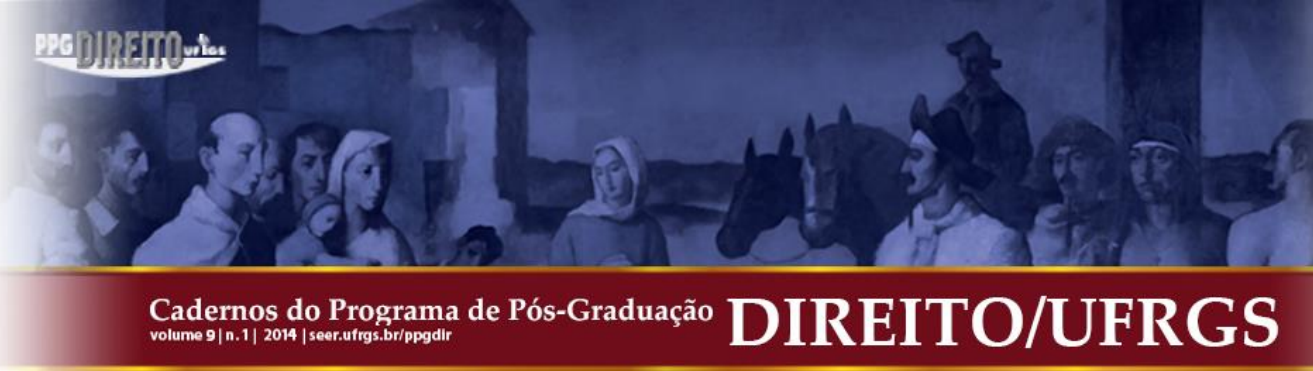

Sabe-se, especialmente, que direitos como a vida e a integridade física não podem ser transferidos por meio de um pacto político entre o súdito e o soberano. Desta forma, o soberano não poderia ordenar a alguém que se matasse ou se mutilasse, bem como não poderia ordenar aos súditos a abstenção de itens fundamentais para a sua sobrevivência, como alimentação. ${ }^{6}$ Mesmo aquele que fosse acusado de um crime, não seria obrigado a confessálo; bem como um soldado que se recusasse a lutar não seria punido por deserção, se colocasse outro em seu lugar. A mesma regra de desobediência valeria em todas as circunstâncias em que a lei silenciasse a respeito. Por outro lado, se o pacto entre súdito e soberano visava a segurança do primeiro, toda vez que o segundo não a garantisse, o súdito não estaria obrigado a ficar indefeso, a mercê de seus inimigos. Em síntese, no pactum societatis do modelo de Estado hobbesiano, ninguém poderia firmar um pacto para recusar a si próprio. A liberdade limitada dos súditos tem sua base na legitimidade de um soberano que tudo pode até o momento em que é reconhecido como legítimo soberano, garantidor do pacto, e não como aquele que falhou na sua prestação em relação aos seus súditos.

Hobbes era um pensador cuja teoria pode ser comentada à luz do pensamento conservador clássico ${ }^{7}$, tendo Burke como um de seus principais representantes. Burke era um dos pensadores que acreditava que a manutenção da desigualdade correspondia a um direito natural de cada povo, e todo seu conservadorismo era voltado para a preservação de um regime político assentado no paradigma de um Estado absolutista, onde, legitimado pelo poder político, o soberano poderia manter a ordem, assegurando a permanência das diferenças de classe oriundas de uma natural desigualdade social. Em certo ponto, suas concepções não se diferenciam intensamente da sociedade hobbesiana. ${ }^{8}$ Afinal, nesse modelo de sociedade existiam aqueles que nasceram para governar, pois detinham a legitimidade para serem soberanos, enquanto que outros estavam fadados a obedecer, pela sua permanente condição de súditos. Numa realidade mantida entre ordem e obediência, a resistência inicialmente é sempre considerada como uma manifestação contrária à ordem, violadora da legalidade, e,

\footnotetext{
6 "Se o soberano ordenar a alguém (mesmo que justamente condenado), que se mate, se fira ou se se mutile a si mesmo, ou que não resista aos que o atacarem, ou que se abstenha de usar os alimentos, o ar, os medicamentos, ou qualquer outra coisa sem a qual não poderá vier, esse alguém tem a liberdade de desobedecer". HOBBES, Op. cit., p. 133.

${ }^{7}$ NETTO, Leila Escorsim. O conservadorismo clássico. São Paulo, Cortez, 2011, p. 63.

${ }^{8}$ SOARES, Mário Lúcio Quintão. Teoria do estado: novos paradigmas em face da globalização. São Paulo: Atlas, 2011, p. 58.
} 


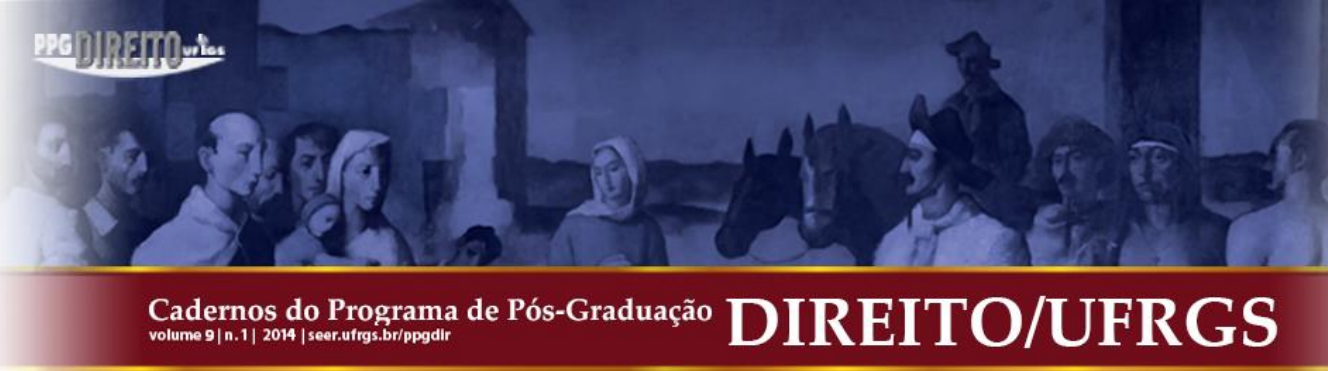

da liberdade individual, por meio da regulação das condutas humanas não por meio de sanções, mas objetivamente pela regulação de preceitos que normativamente expressam direitos e a forma de exercê-los.

Ordem e resistência são conceitos que aparecem como contrapostos, no pensamento de Hobbes, e é isso por isso que a última é vista como uma exceção à regra geral de que competiria ao soberano sempre conter a rebelião, por se tratar de um crime contra o soberano $^{12}$. A desobediência não é vista como uma regra, e sim como um ilícito, uma violação da regra que pode levar aquele que desobedece a regra a cometer crimes. Tais crimes são em sua maioria atribuídos às paixões humanas ou a defeitos de raciocínio, como o erro ou ignorância sobre a lei, especialmente nos casos em que a ignorância não poderia ser alegada como desculpa quando existisse uma lei declarada. Entretanto, mesmo baseado numa doutrina da ordem, em que o papel da lei consistiria principalmente em reafirmar o poder do soberano por meio da coerção aflitiva da pena na repressão aos crimes, Hobbes entendia que os homens seriam capazes de violar a lei de forma justificada, como nos casos daqueles que se encontrassem privados de alimentos e de outros elementos necessários a sua vida, podendo preservá-la somente com a violação da lei $^{13}$. Nesses casos, entendia ele que tais condutas poderiam ser desculpadas e não punidas como crimes, mesmo que estas implicassem em crimes contra o patrimônio, tais como o furto ou o roubo.

Desta forma, diante de uma realidade de fome, insegurança e ausência de direitos, mesmo no conservadorismo hobbesiano seria possível conceber a resistência como conduta legítima, mediante a desobediência ou mesmo violação da lei civil, sem que isso implicasse numa responsabilização penal. Afinal, se um dos compromissos do soberano no pacto é a manutenção da paz social, tal paz passaria pela satisfação dos interesses e necessidades mínimas de um povo, tais como a manutenção de sua própria sobrevivência. Numa nação de deserdados e miseráveis que sequer tiveram sua quota de participação no pacto, a rebelião seria até previsível.

Já na obra de John Locke, sob o prisma do liberalismo político, encontra-se o cerne filosófico do direito de resistência. O Estado existe apenas como um meio para garantir a

\footnotetext{
12 BUZANELLO, Op. Cit., p. 57.

13 Observa-se que por mais que o discurso de Hobbes seja legalista e defensor de uma ordem monolítica do soberano em prol da lei civil (resultante do pacto), havia em sua obra exceções com base no direito natural de alguém de preservar a própria vida: "Se alguém for obrigado, pelo terro de uma morte iminente, a praticar um ato contrário à lei, fica inteiramente desculpado, porque nenhuma lei pode obrigar um homem a renunciar a sua própria preservação". HOBBES, Ibid., p. 181.
} 


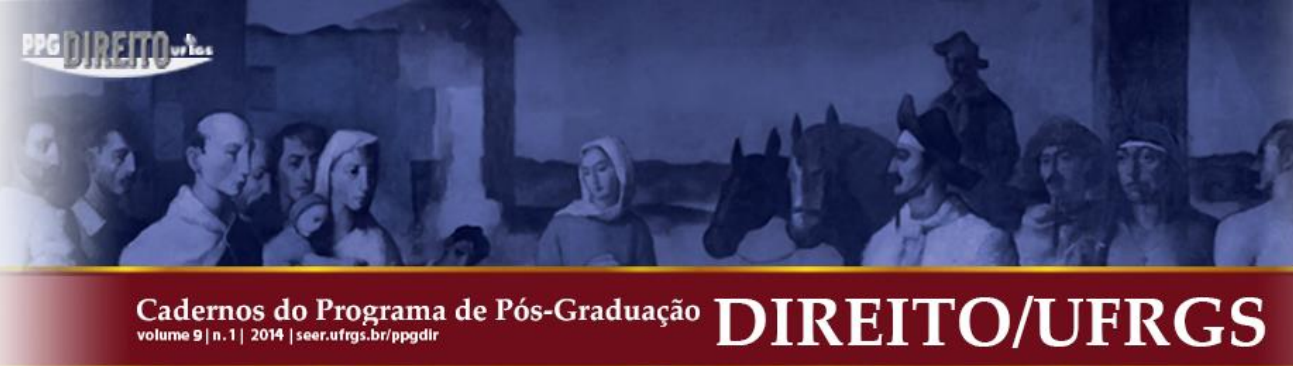

também o governo, cabendo a instituição de um novo parlamento, que siga os interesses do povo que o instituiu. ${ }^{18}$

Em ambos os aspectos filosóficos em que foi abordado o fenômeno da resistência, tanto na obra de Hobbes como na de Locke, observa-se que há um desvio no pacto, uma falta de compromisso do governante com o que foi acordado na constituição da comunidade civil. Não é à toa que, com os sucessivos conflitos sociais e violentas rebeliões que surgiram historicamente em virtude disso, face à manutenção das desigualdades (e suas respectivas injustiças) sociais, o ordenamento jurídico dos povos voltou-se ora mais para a legitimação da força, na manutenção da ordem por parte do poder político estatal, ora para o reconhecimento e consagração de direitos, homologando conquistas obtidas por meio das lutas sociais.

Acerca da resistência e da desobediência civil, para teóricos como o lusitano Boaventura Santos, por sua vez, o Direito encontra seu marco divisório entre uma função histórica de tensão entre regulação e emancipação de condutas (ora reconhecendo direitos por meio das lutas dos povos, ora reprimindo condutas tidas como uma violação da ordem estabelecida). ${ }^{19}$ Se os homens firmam um pacto de convivência e erigem uma ordem política e jurídica a partir do contrato, por meio da manifestação de vontades, é certo que a vontade individual de cada integrante do pacto pode ser boa ou má, mas na acepção de Rousseau, a vontade geral resultante do pacto é sempre uma vontade boa. Isso não significa dizer que a vontade geral coincide com a vontade de todos; mas sim que um interesse comum preponderou sobre as paixões e apetites individuais. Dessa forma, o exercício da regulação coincidiria com o exercício da emancipação, uma vez que o Direito não teria apenas uma função meramente coercitiva, orientadora de condutas mediante uma regulação prescrita em leis, mas também teria uma função claramente educativa, servindo como um princípio ético a serviço da vontade geral e um eficaz instrumento de ordenação e transformação social. ${ }^{20}$

A teoria de Rousseau é uma teoria de legitimação da ordem social por meio do Direito, visto que esta funciona como suporte para todos os homens como um direito sagrado decorrente da associação entre os homens em busca de um bem comum, apesar de não provir do estado da natureza e sim de convenções que os homens mantém entre si no seu pacto de sociabilidade. ${ }^{21} \mathrm{O}$ Estado, enquanto corpo moral e coletivo, é um mero executor das decisões

\footnotetext{
${ }^{18}$ BUZANELLO, Op. Cit., p. 67.

${ }^{19}$ SANTOS, Boaventura de Sousa. A crítica da razão indolente. São Paulo: Cortez Editora, 2000, p. 130.

${ }^{20}$ SANTOS, Op. cit., p. 31.

${ }^{21}$ ROUSSEAU, Jean-Jacques. Do contrato social. São Paulo: Martins Fontes, 1996, p. 9.
} 


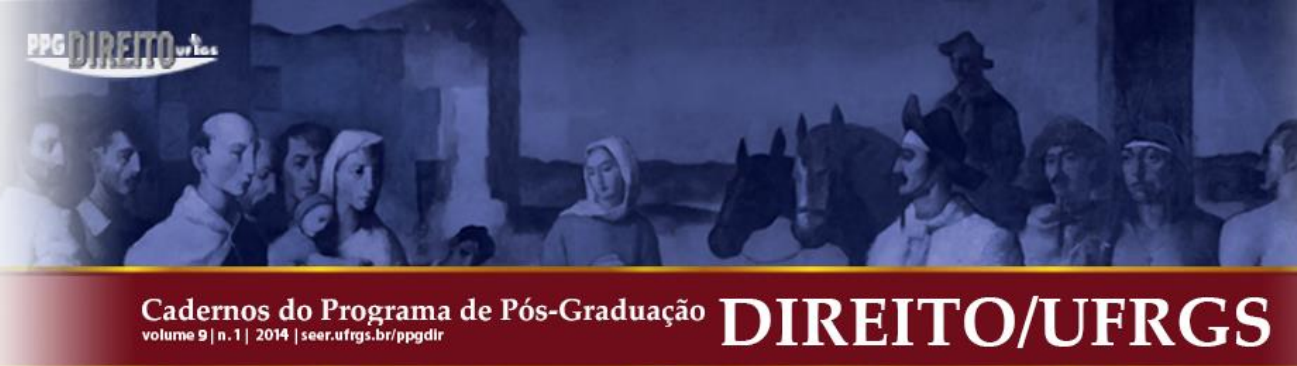

da vontade geral dos membros de uma sociedade, entendida, portanto, como uma vontade soberana. ${ }^{22} \mathrm{O}$ povo, em sua totalidade, é que é o detentor da soberania, sendo chamado a elaborar as leis que regerão suas condutas. É por isso que Rousseau firma sua teoria de Estado e sociedade em termos de uma soberania popular, no lugar de uma soberania absoluta na figura do monarca, apregoada por Hobbes, ou numa soberania legislativa, preconizada por Locke. Se é o próprio povo quem governa, as tomadas de decisão são soberanas, pois dizem respeito à vontade geral, e qualquer forma de resistência, nesse sentido, seria uma resistência do cidadão contra si próprio, uma vez que sua vontade individual pode até não convergir para a vontade geral, mas os interesses compartilhados universalmente por todos acabam por subordinar essa vontade à ação do Estado, como executor de uma onipresente vontade geral.

Uma vez superado historicamente o Estado absolutista, dando lugar ao Estado liberal, e posteriormente ao Estado social, erigido nos termos da soberania popular, o Direito aparece mais como instrumento de regulação e menos como de emancipação, sendo cada vez mais refratário a uma ideia de resistência, uma vez que, no ideal rousseauniano, a regulação nunca sufocaria a emancipação de direitos, pois equilibraria liberdade e igualdade, autonomia e solidariedade, autoridade e consentimento, por meio de um Direito que representasse a vontade geral. ${ }^{23}$

Mas, onde estaria a resistência num paradigma de Estado social onde o cidadão não obedece mais do que a si próprio, não sendo forçado a nada senão a ser livre, no modelo de Estado assentado na vontade geral que Rousseau defendeu? O problema é que o Estado constitucional que surge no século XIX, inspirado nos ideais liberais de Locke e sociais de Rousseau, é baseado num paradigma de Direito enquanto instrumento de regulação, que tem sua base teórica no positivismo, nova corrente teórica e consciência filosófico do fenômeno jurídico, que irá influenciar todo o Direito moderno a partir desse período histórico. ${ }^{24}$

O positivismo no âmbito do Direito moderno conferiu ao Direito um perfil cientificista e estatista. Tal doutrina filosófica adequou-se como uma luva à necessidade de regulação racional da produção fabril da economia capitalista; bem conforme os ideais do Estado liberal, bem como no aspecto jurídico, o pensamento positivista reforçou a autoridade do Estado em torno de normas cogentes, que, outrora concebidas como manifestação do poder absoluto do soberano no ideal conservador hobbesiano, agora apareciam como resultado da vontade geral

\footnotetext{
${ }^{22}$ SOARES, Op. cit., p. 70.

${ }^{23}$ SANTOS, Op. cit., p. 132.

${ }^{24}$ SANTOS, Ibid., p. 141.
} 


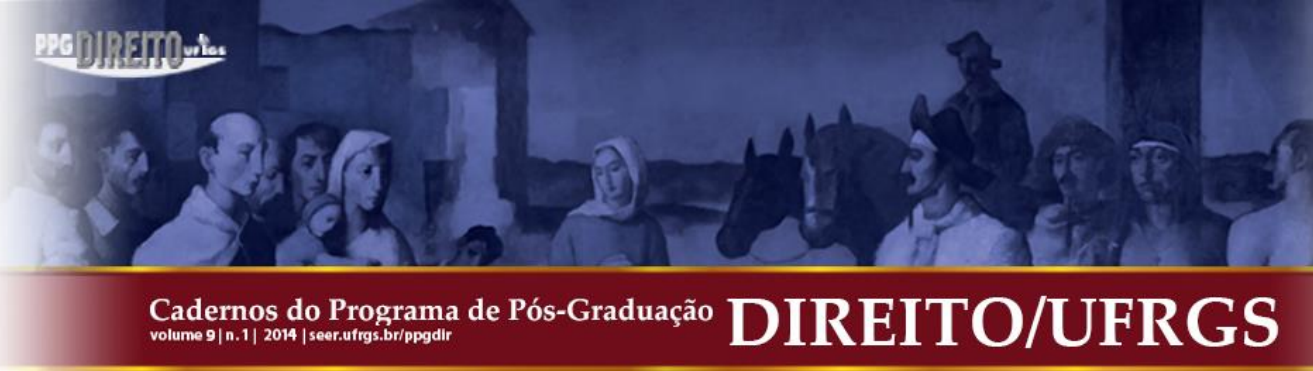

no Estado constitucional, assentado num ordenamento de leis hierarquicamente dispostas e orientadas nos termos de uma lei fundamental.

Assim, a resistência passou a se limitar à liberdade de determinados atos e práticas que não atentassem contra uma ordem jurídica concebida como ordem ideal, pois baseada num Direito estatal que era, sobretudo, a expressão da vontade geral, consagrada em um texto constitucional. Sob a égide do positivismo jurídico, todo fenômeno jurídico passou a ser concebido como Direito estatal, e toda e qualquer manifestação atentatória a esse Direito, traduzida por meio de desobediências ao texto legal ou violações premeditadas da norma como forma de protesto, para a afirmação de novos direitos (a ocupação de terrenos e prédios públicos, por exemplo), passou a ser concebida como violação da norma, e, portanto, uma violação de uma ordem racional consagrada no contrato social que não poderia passar impune, sem receber uma sanção.

No âmbito do moderno Estado Constitucional inspirado no modelo positivista, ainda a persistir na atual perspectiva brasileira, o direito de resistência pode ser exercido somente por meio de formas plenamente previstas no sistema jurídico do Direito oficial, por meio do exercício do direito de petição, previsto constitucionalmente (art. $5^{\circ}, \mathrm{XXXIV}$, "a” da CF), onde podem ser propostos mecanismos de negociação, com apresentação de propostas e tentativas de acordos, além da greve política e da desobediência civil em áreas sensíveis da estrutura do Estado. ${ }^{25}$ Outras formas de manifestação que envolvam, por exemplo, a ocupação do espaço público como ruas, praças ou edificações públicas pode ser caracterizada como esbulho ou mera invasão, ou mesmo como crime de dano ao patrimônio público, se porventura algum objeto ou bem móvel situado no local apresentar algum sinal de deterioração por conta da atuação de manifestantes insuflados. Mesmo sob o argumento de que ruas são ocupadas, pelo fato de que os principais direitos consagrados no pacto social nos termos de uma Constituição não estão sendo contemplados pelo descaso ou abuso do Estado, tais como o direito à vida, garantido constitucionalmente por meio dos direitos à saúde ou o direito à segurança, tais ocupações são sistematicamente tratadas como violação da norma, e, portanto, cabe a reação estatal de tratar tais manifestos como casos de polícia, valendo-se o Estado de todo o aparato repressivo de que dispõe. O Leviathan concebido por Hobbes retorna com toda força no século XXI, diante de uma sociedade modernamente globalizada; resta saber se a resistência contra o soberano que já era prevista na obra do filósofo inglês, cinco

${ }^{25}$ BUZANELLO, p. 243. 


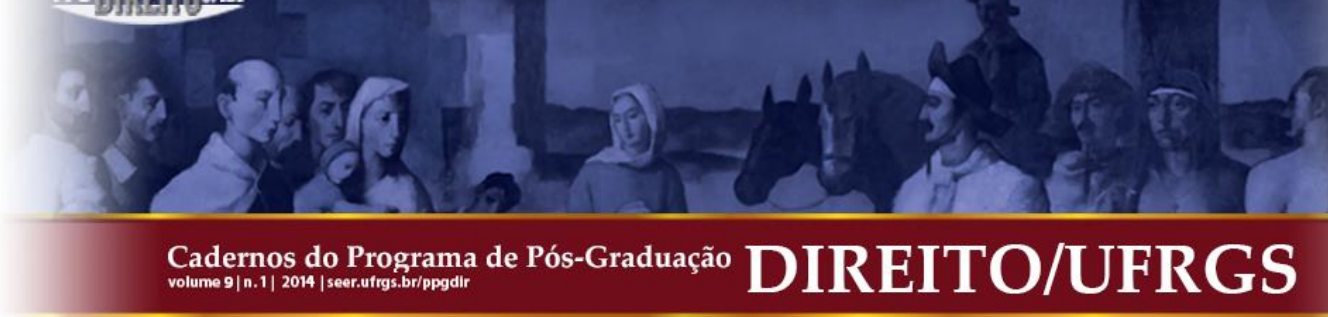

séculos antes, também pode ser empregada nos tempos atuais, mormente na realidade de protestos e manifestações dos movimentos sociais no Brasil.

\section{A CRIMINALIZAÇÃO DOS PROTESTOS NO BRASIL POR MEIO DA LEI 12.850 DE 2013: SERIAM OS BLACK BLOCS OS NOVOS INIMIGOS DO ESTADO?}

No que tange aos protestos iniciados desde junho de 2013 nas grandes capitais e centros urbanos do país, e a crescente presença de coletivos anarquistas, alguns deles focados em táticas violentas de violação da ordem, como os intitulados Black Blocs, observa-se que o discurso dominante do Estado é o da responsabilização penal desses grupos, com base na aplicação da Lei $n^{0}$ 12.850, sancionada em 02 de agosto de 2013, pela presidente Dilma Roussef. Na citada lei, destinada a definir o conceito de organizações criminosas no Brasil, logo em seu início, no parágrafo $1^{\circ}$ de seu artigo $1^{\circ}$, a definição de organização criminosa é estabelecida nos seguintes termos:

$\S 1^{\circ}$ Considera-se organização criminosa a associação de 4 (quatro) ou mais pessoas estruturalmente ordenada e caracterizada pela divisão de tarefas, ainda que informalmente, com objetivo de obter, direta ou indiretamente, vantagem de qualquer natureza, mediante a prática de infrações penais cujas penas máximas sejam superiores a 4 (quatro) anos, ou que sejam de caráter transnacional.

Tal dispositivo legal foi utilizado no caso das manifestações dos chamados militantes Black Blocs nos protestos na cidade do Rio de Janeiro, onde, num primeiro momento, os aparatos de segurança pública consideraram tais indivíduos como suspeitos de participação em grupos criminosos previstos na Lei 12.850, como se os protestos onde foi empregada certa dose de violência na reação dos manifestantes à ação da polícia fosse considerada como conduta típica de uma associação criminosa. ${ }^{26}$

Entretanto, os próprios meios de comunicação que, inicialmente divulgaram os Black Blocs como um novo (e violento) movimento social, tiveram que voltar atrás ou constatar que tal grupo não é necessariamente um movimento, mas sim uma tática de agitação popular desenvolvida por alguns movimentos sociais na Europa, onde manifestantes mascarados

\footnotetext{
${ }^{26}$ CALDAS, Andressa, Eduardo Backer. Criminalização do protesto social e o fenômeno Black Bloc:surge um novo inimigo interno. Le Monde Diplomatique Brasil. Acesso em: dez. 2013. Disponível em: <http://www.diplomatique.org.br/artigo.php?id=1554>.
} 


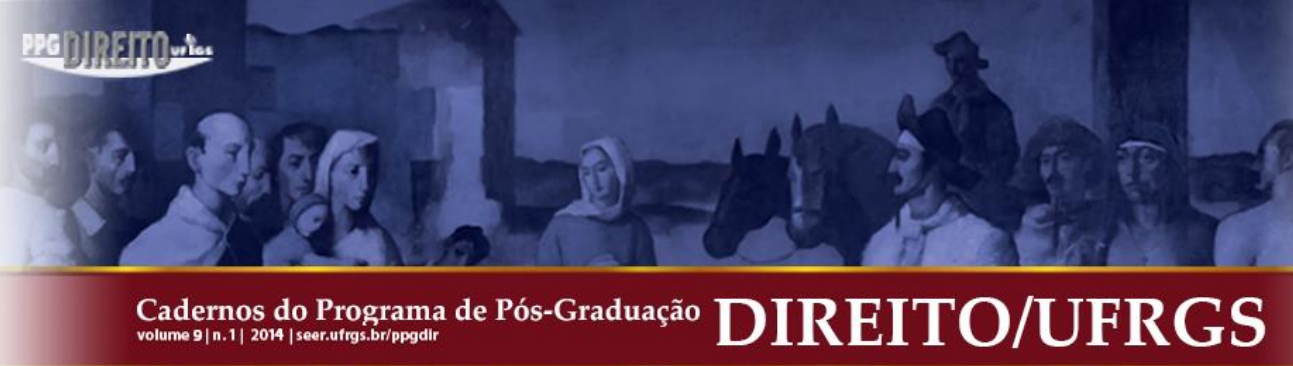

enfrentam a polícia, no momento de grandes turbulências em protestos de rua, devido a aguçados conflitos sociais.

Por outro lado, interpretações parciais da norma, no caso dos manifestantes mascarados intitulados Black Blocs, que façam entender que tais grupos ou movimentos que se valem de táticas de mascaramento para preservação do anonimato de seus integrantes, seriam na verdade organizações criminosas, talvez pequem por um reducionismo que nem o pior dos legalismos cegos poderiam obliterar. Em primeiro lugar, não restou provado que tais grupos estivessem presentes nas manifestações de rua (junto com milhares de outras pessoas que saíram livremente para protestar) apenas para praticar delitos; principalmente aqueles referidos no artigo $1^{\circ}$ da Lei 12.850 , cujas penas máximas seriam superiores a quatro anos. Também não prosperaria a tese de configurar tais grupos como organizações terroristas, visto que, em nenhuma de suas ações, exaustivamente divulgadas pelos meios de divulgação, tais grupos pretendessem afrontar indivíduos da sociedade, ou destruir patrimônios que não representassem ou não fossem associados ao aparato repressivo ou financeiro do Estado. $\mathrm{Na}$ verdade, a responsabilização individual de cada integrante desses movimentos que, comprovadamente, apresentasse em sua conduta os elementos identificadores de uma conduta penalmente típica, poderia, aí sim, ser ele responsabilizado criminalmente, como no caso de crimes contra a pessoa ou contra o patrimônio. Mas o âmbito da responsabilidade criminal, ao menos no que tange aos integrantes de movimentos sociais, não pode ser delimitado por meio da imputação de condutas delituosas a toda uma generalidade de práticas de uma coletividade em protesto, mas tão somente a condutas isoladas, individualmente definidas.

Importante salientar nesse momento de reflexão sobre o tema da criminalização, como o Direito constitucional e o Direito penal por vezes se confrontam, firmando uma tensão entre norma constitucional e ordenamento infraconstitucional que se não leva a uma discussão sobre a inconstitucionalidade, ao menos faz o intérprete da norma jurídica questionar até que ponto o sistema do Direito está sendo empregado pelo Estado como meio de minar movimentos de resistência, por meio da aplicação de sanções penais. Iniciativas legislativas que tem por escopo responsabilizar criminalmente integrantes de protestos e manifestações por eventuais danos a bens jurídicos, legalmente considerados, tem como ultima ratio o propósito de reeditar o velho espectro de uma responsabilidade penal coletiva, que não se coaduna com o dispositivo constitucional anteriormente citado. Assim, a aplicação da Lei 12.850 para condutas de grupos ou coletividades organizadas que, eventualmente, possam ser 


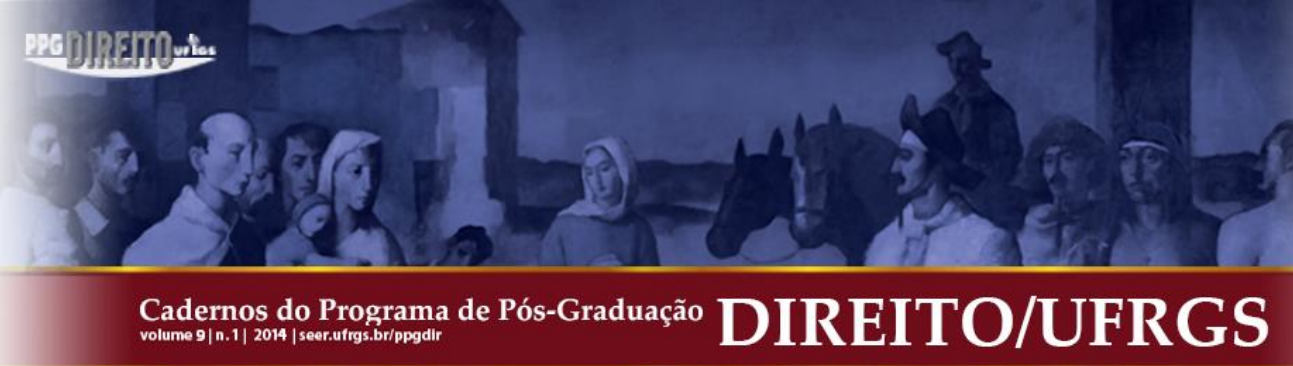

atribuídos excessos ou abusos decorrentes das manifestações que ocorrem desde junho de 2013, poderia ser não apenas precipitada, como também fomentadora de uma eventual medida punitiva inconstitucional.

Ora, no âmbito da responsabilidade penal, prevista constitucionalmente por força do disposto no artigo $5^{\circ}$, inciso $\mathrm{XLV}$, assim como a individualização de uma pena é direito fundamental de alguém que foi condenado, ao ser responsabilizado pela prática de um delito, como em qualquer conduta humana, a imputação da responsabilidade por danos causados a outrem obriga diretamente a quem o provocou sua reparação. O Código Penal francês, por exemplo, em seu artigo 64, exclui a reponsabilidade penal em determinados casos, afirmando que "não há crime, nem delito nos casos em que o acusado se encontrar em estado de demência no momento da ação ou quando for coagido por uma força à qual não puder resistir". ${ }^{27}$ Se o Direito Penal funda-se na responsabilidade pessoal, que exige que cada um responda pela infração cometida de acordo com sua vontade própria, como responsabilizar penalmente uma multidão, uma turba em protesto, quando de forma violenta um grupo considerável de pessoas revoltadas decide entrar em rebelião? A culpa pelo fato de outrem é, em regra, descartada pela norma penal, uma vez que a responsabilidade penal somente pode resultar do fato produzido por alguém que o causou. ${ }^{28}$ Entende-se que, nesses casos, a intenção do legislador não era de impor a repressão penal por meio do encarceramento de seus integrantes, mas sim a garantia de um pagamento ao Estado por meio da fixação de multas. É assim que funciona no Brasil, por exemplo, no âmbito da responsabilidade penal ambiental, prevendo-se a aplicação da pena de multa a pessoas jurídicas para crimes ambientais, conforme o artigo 21, inciso I da Lei n ${ }^{\circ}$ 9.605, de 1998, quando não for o caso da aplicação de sanções mais graves, previstas no artigo seguinte, como a suspensão parcial ou total de atividades ou a interdição temporária de estabelecimento, obra ou atividade.

De qualquer forma, quaisquer imposições de sanções a coletividades organizadas, mormente no caso dos movimentos sociais, necessitariam de uma análise minuciosa, à luz dos dispositivos constitucionais. Segundo Marcelo Neves, apesar da complexa sociedade moderna ter como uma das características de sua complexidade, uma multiplicidade de valores e interesses que leva a uma pluralidade de interpretações da norma constitucional, o problema estaria em delimitar quais interpretações seriam constitucionalmente justificáveis e quais

27 DELMAS-MARTY, Mireiile. A imprecisão do direito: do código penal aos direitos humanos. Barueri: Manole, 2005, p. 31.

${ }^{28}$ DELMAS-MARTY, Op. Cit., p. 33. 


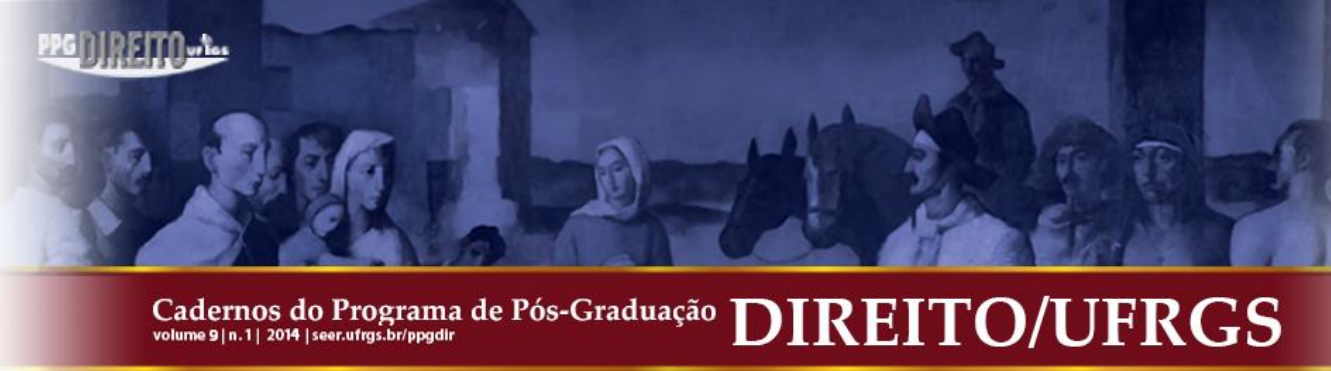

estariam fora das fronteiras do texto constitucional, num Estado Democrático de Direito. ${ }^{29}$ Questões relacionadas ao exercício da liberdade de expressão e reunião, no fundamento do direito de manifestação de determinados movimentos e grupos sociais de contestação políticosocial, pode se tornar um dos hard cases que levam muitos estudiosos a analisar até que ponto podem ser definidos os limites constitucionais desses movimentos, principalmente diante de mobilizações violentas e de confronto aberto com a autoridade, realizadas por alguns setores ideologicamente vinculados a um ideal revolucionário de ruptura violenta da ordem vigente.

A saída apontada por Neves parte do modelo sistêmico luhmanniano de redução de complexidade do processo interpretativo do texto constitucional, diante de uma heterogeneidade de valores diante de uma esfera pública desenvolvida no Estado Democrático de Direito. Como o caminho para a solução interpretativa só pode ser encontrado no próprio texto constitucional, e sabendo-se que sua linguagem, diante de uma sociedade complexa e pluralista, é provida de vagueza e ambiguidade, caberia ao intérprete se valer da saída apontada por Neves é encontrada numa leitura de Wittgenstein acerca da estranheza de sentido de determinados enunciados interpretativos. ${ }^{30}$ Um enunciado estranho, assim, seria aquela cuja interpretação conforme a Constituição seria absurda, implausível, totalmente estranha às regras do jogo democrático em que se desenvolve a linguagem dos atores políticos na esfera pública.

Mas se a linguagem parte pelo discurso do protesto resta saber se, no Estado Democrático, tal discurso pode vir acompanhado de ações políticas de confronto que conceituam aquilo que pode ser chamado como desobediência civil. Nesse sentido, a ocupação de prédios públicos pode revelar até que ponto é permitido o exercício do protesto enquanto forma de mobilização social pelo confronto, sem que isso seja considerado pelo Direito oficial como a mera prática de violação de normas estatuídas.

\footnotetext{
${ }^{29}$ NEVES, Marcelo. Entre Themis e Leviatã. São Paulo: Martins Fontes, 2008, p. 207.

${ }^{30}$ NEVES, Op. cit., p. 211.
} 


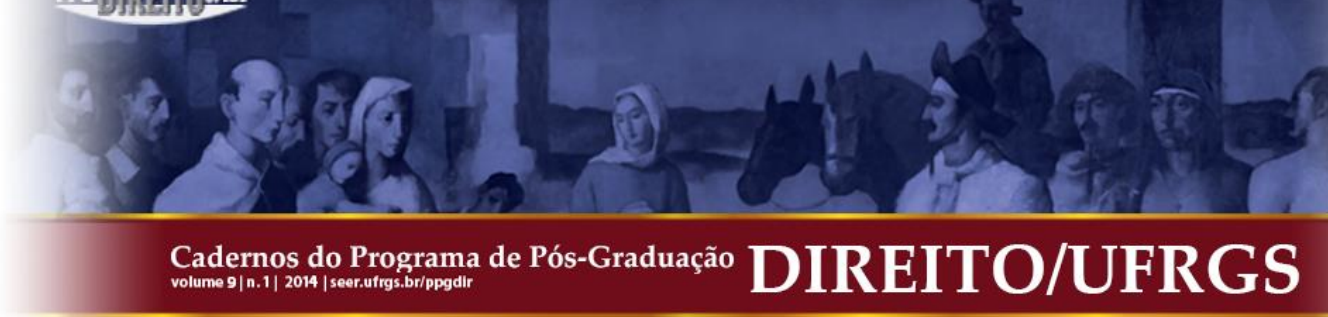

\section{SISTEMA JURÍDICO FUNDADO NO DIREITO OFICIAL E O DIREITO DOS DIVERSOS SUBSISTEMAS SOCIAIS, NA TENSÃO ENTRE UM DIREITO EMANCIPATÓRIO E UM DIREITO REGULATÓRIO}

Na sociologia do Direito de Luhmann, observa-se que o Direito é firmado por expectativas que lidam com a frustração padronizando determinados comportamentos, exigindo-lhes uma padronização generalizada. ${ }^{31}$ Concebendo as relações sociais enquanto comunicações que propiciam certa seletividade, diferenciando-se determinadas práticas sociais de outras, o que forma os sistemas, Luhmann entendia que o mundo era construído sensorialmente pelos homens, o que implicaria em transformar o indefinido em palpável, por meio de uma operação mental de redução de complexidade. ${ }^{32}$ A complexidade formada pela possibilidade que o mundo sensorial apresenta, lidaria com uma contingência, composta pela gama de possibilidades que seriam diferentes daquelas esperadas. Assim, o Direito surge como um engenhoso sistema social que procura lidar com a contingência, com a possível frustração de que determinadas expectativas de comportamento sejam exatamente como as esperadas e que não comprometam as relações sociais a ponto de não haver comunicação, e, portanto, não existir sistema.

Mas como o Direito vislumbra as ações prestadas pelos movimentos sociais, enquanto situações que podem ser concebidas como operações próprias do sistema jurídico? Como tais movimentos podem se apresentar como comunicações, a fim de que a emancipação se transforme em regulação no que tange ao exercício do direito de protesto ou da resistência? $\mathrm{Na}$ lógica luhmanniana de se conceber o ordenamento jurídico enquanto um sistema autopoieticamente fechado, a compreensão das condutas de protesto como previstas dentro das comunicações internas desse sistema, passa pela aplicação do código lícito X ilícito; ou seja, dentro das expectativas normativas de um determinado sistema de Direito ${ }^{33}$. Conforme o sistema jurídico observa determinadas condutas como parte de suas operações internas, logo se terá a definição daquelas condutas consideradas lícitas e aquelas lícitas, sempre tendo inicialmente como base um sistema jurídico que corresponda a um Direito oficial estatal, conforme a lógica do positivismo jurídico. Nesse contexto, o Direito enquanto instrumento de

\footnotetext{
${ }^{31}$ LUHMANN, Niklas. Sociologia do direito. Rio de Janeiro: Tempo Brasileiro, 1983, p. 45.

${ }^{32}$ LUHMANN, Niklas. Op. Cit., p. 54.

${ }^{33}$ LUHMANN, Op. Cit., p. 57.
} 


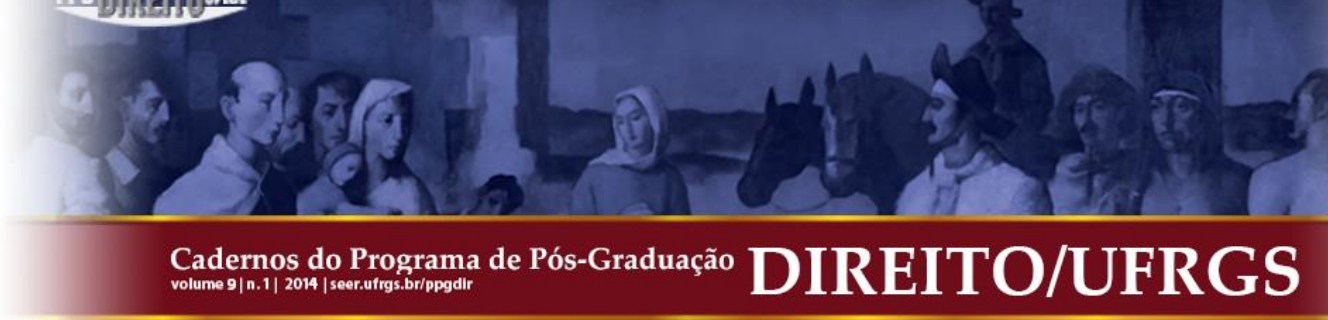

regulação ou emancipação, no que tange à classificação da resistência, pode apresentar as seguintes dimensões:

\begin{tabular}{|c|l|}
\hline NO DIREITO EMANCIPATÓRIO & NO DIREITO REGULATÓRIO \\
\hline a) Supedâneo do direito de liberdade & a) Infração ou violação do Direito. \\
(liberdade de expressão) & $\begin{array}{l}\text { Identificação da prática de uma conduta } \\
\text { ilícita ou reprovável socialmente (caso dos } \\
\text { vandalismos). }\end{array}$ \\
& b) Violência conforme as diretrizes \\
normativas do lícito; ou seja, como & Violência, contrária às expectativas \\
uma das formas de manifestação & normativas, vista como mera violação da \\
da resistência esperadas pelo & \\
próprio sistema. & \\
\hline
\end{tabular}

Compreender as manifestações populares como exercício de uma liberdade coletiva ou concebê-las como baderna resumida em atos de vandalismo são duas das possibilidades com que o sistema jurídico irá lidar, no momento em que o sistema é chamado a estabilizar expectativas quanto ao mundo circundante a essas peculiares comunicações. Para Luhmann tal questão passa pela característica de dupla contingência do mundo social; ou seja, reconhecer as expectativas dos outros como suas próprias expectativas. ${ }^{34}$ A experiência das comunicações num ambiente social somente é completada quando as ações do outro são reconhecidas como ações próprias, quando alguém tem a liberdade de variar seu comportamento, da mesma forma que o outro também pode assim se portar. No âmbito da experiência brasileira, as recentes manifestações populares chamaram às ruas multifacetadas coletividades, com as mais diversas formações e mais diferenciados perfis etários, de gênero, ofício, raça ou classe, demonstrando uma insatisfação geral de uma grande soma de grupos de indivíduos que, de forma comum, ocuparam ruas, paralisaram o tráfego de grandes urbes, comprometendo o transporte rodoviário ou, em alguns casos, até danificando objetos pertencentes ao patrimônio público; mas com uma impressionante marca de aprovação e adesão popular. Nesse panorama de rebeldia e protesto, mesmo nos marcos de um Direito

${ }^{34}$ LUHMMAN, Ibid., p. 47. 


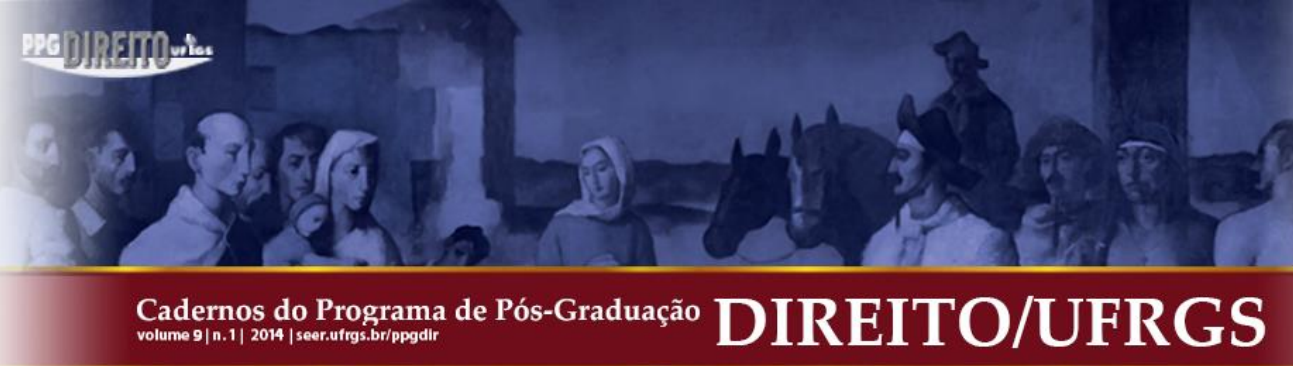

conceber uma pluralidade de experiências sociais, que no âmbito da sociologia do Direito, por exemplo, pode levar ao conceito de pluralismo jurídico e a possibilidade de existirem expectativas normativas distintas daquelas previstas no Direito oficial.

O conceito de sistema já implica em uma diferenciação entre o sistema e seu entorno. ${ }^{37}$ Há relações tanto entre o sistema quanto ao seu entorno como uma relação entre sistemas diferenciados. Como o entorno não propicia informação alguma, por ser uma zona cinzenta, localizada além do sistema, o que interessa aqui é diferenciar algo distinto de um sistema social como um outro sistema. Assim, um sistema observa o outro por meio de determinadas observações contingentes, onde sistemas parciais se formam, na medida em que conseguem observar a si próprios como sistemas parciais, diferenciando-se, portanto, de um sistema total. No Direito, tal operação sistêmica opera-se no interior do sistema do Direito oficial, quando, por exemplo, o próprio sistema jurídico do Direito interno de um determinado país concebe-se como sistema constitucional, e deste sistema constitucional desenvolvem-se operações de outros sistemas parciais, de natureza infraconstitucional, como o sistema do Direito civil, do Direito penal etc. Da mesma forma, pode-se conceber no âmbito dos movimentos sociais que o direito de protesto e o de resistência emergem de um princípio de desobediência civil que também segue uma autorreferência enquanto sistema parcial do Direito, concebido não de forma contrária a uma violação de um sistema jurídico constitucional, mas sim de um sistema parcial que tem dificuldades de comunicação com outros sistemas parciais do Direito oficial, como o Direito penal, por exemplo.

O marco entre a dimensão emancipatória do Direito e sua dimensão regulatória pode passar então, no que tange a uma repressão ou reconhecimento de legitimidade das atividades dos movimentos sociais, por uma diferenciação entre os diversos sistemas sociais, concebidos como sistemas parciais dentro de uma pluralidade de experiências jurídicas que podem ser concebidas, no âmbito do pluralismo jurídico, como espécies de subsistemas do Direito. Luhmann não é, de forma alguma, um defensor conservador de um modelo petrificado de sociedade ou de Direito oficial, como um sistema social dominante, que necessariamente deva regular determinada ordem social, a ponto de sua violação ser considerada obrigatoriamente um delito. Ao contrário, em sua teoria é possível conceber que dentro de determinadas ordens sociais oficiais, a sociedade tende a seguir uma evolução em que novas ordens provem do

\footnotetext{
${ }^{37}$ LUHMANN, Nilklas. La sociedad de la sociedade. Ciudad do Méximo: Editorial Herder, 2007, p. 482.
} 


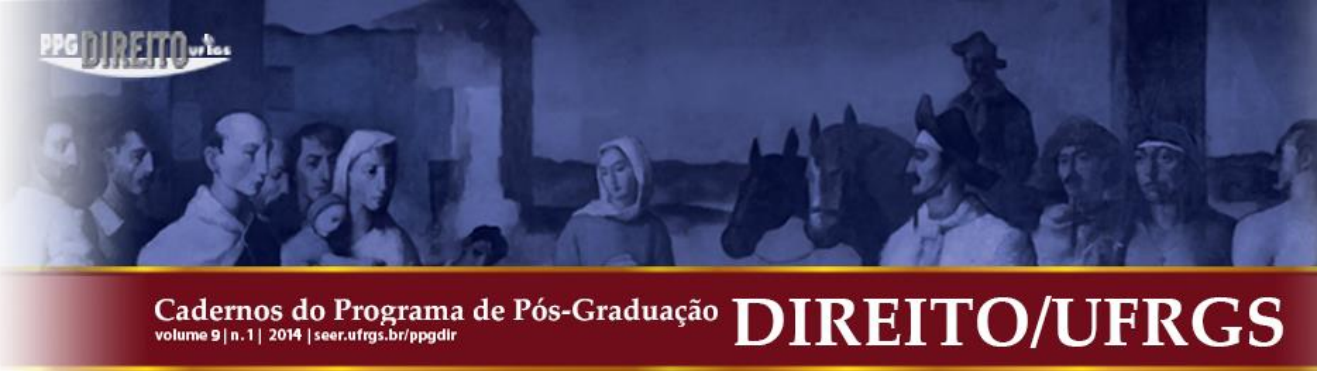

regramento estatal, que será possível encontrar alternativas que senão legitimam à luz de um Direito oficial, ao menos justificam juridicamente o fenômeno da resistência.

Em primeiro lugar, é necessário reconhecer no surgimento de expectativas normativas num determinado sistema social, a prevalência de uma dualidade jurídica envolvendo um Direito legal estatal e um Direito social não estatal. ${ }^{40}$ Se é possível conceber uma realidade do Direito além dos limites do positivismo jurídico, no interior de um sistema social como o que se encontra presente na realidade de grupos ou coletividades em protesto, perante à contingência, determinadas expectativas podem se voltar para orientações normativas concorrentes $^{41}$ entre um Direito oficial e um não oficial, que culmina numa crise regulatório do primeiro. Isto implica numa possível postura de desobediência em relação a determinados comandos ou imperativos normativos, não obstante existir uma informação psíquica acerca da licitude ou ilicitude de uma conduta de quem a pratica, conforme os moldes do sistema do Direito oficial, mas não existe uma informação social correlata, a caminhar no mesmo sentido de compreensão, uma vez que tal informação já se encontrada orientada socialmente para uma programação voltada a outras expectativas, que não a do sistema legal vigente. Num primeiro momento, é como se a prática de desafiar a polícia, pinchar muros e paredes de prédios públicos, quebrar vidraças ou fazer ruidosas paralisações de tráfego, em ações capitaneadas por alguns movimentos, fossem concebidas normativamente como parte do exercício de um Direito, do que propriamente a prática de um ilícito, não obstante a compreensão daquele que exerce a conduta de que, no âmbito do Direito oficial, tal prática pode gerar uma coercitiva reprovação por parte das normas estatais.

Teubner considera que o problema da regulação jurídica é um problema de aprendizado, revelado num momento de maior ou menor "surdez jurídica" acerca de pretensões de diferentes ramos ou domínios do Direito, no âmbito do discurso. ${ }^{42} \mathrm{~A}$ efetividade do Direito penal oficial depende menos da eficácia de sua sanção, do que de sua observância, que se dá em graus diferenciados, conforme a intensidade dos desvios produzidos por orientações normativas distintas possam atingi-lo a ponto de não ser mais

\footnotetext{
${ }^{40}$ Levando em conta os estudos de Joaquim Falcão, acerca de conflitos de propriedade na periferia urbana de Recife, é possível perceber a existência de práticas jurídicas paralelas a um Direito oficial, que podem tanto estabelecer uma convivência consensual como contraditória com o Direito legal vigente. WOLKMER, Antonio Carlos. Pluralismo jurídico: fundamentos de uma nova cultura do direito. São Paulo: Editora Alfa Ômega, 2001, p. 216.

${ }^{41}$ TEUBNER, Günther. Direito, sistema e policontexturalidade. Tradução Brunela Vieira de Vincenzi e outros. Piracicaba: Editora Unimep, 2005, p.26.

${ }^{42}$ Ibid, p. 31.
} 


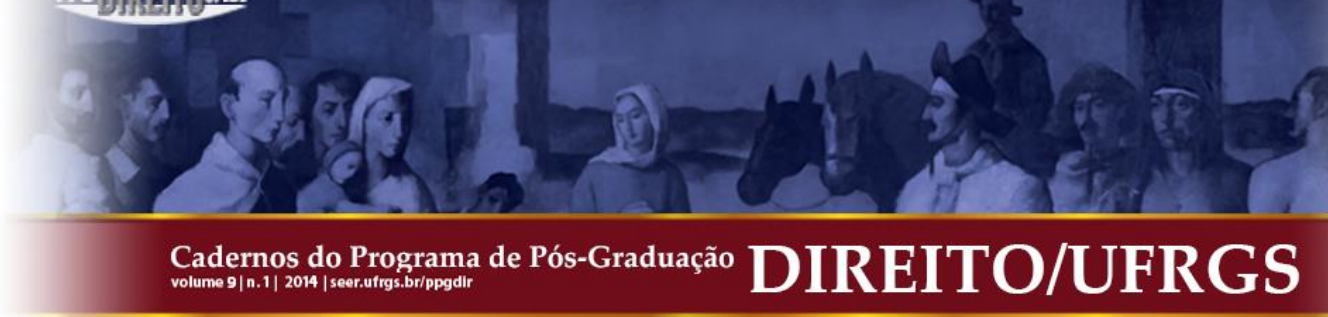

observado e consequentemente cumprido. Quando uma multidão rebelada e organizada decide desafiar o Leviatã, como as normas de um Estado abalado em sua legitimidade política podem ser aplicadas? Mesmo no âmbito da economia, a "irritação" do sistema do Direito pelo sistema da economia compromete a integridade do primeiro, quando normas jurídicas são obrigadas a se adaptar às pressões externas, oriundas do entorno ao sistema que lhes abarca, não perdendo o conteúdo de sua juridicidade, mas comprometendo em certo grau a sua eficácia.

O pluralismo jurídico estabelece uma relação ambígua entre Direito e sociedade, mantendo até mesmo um paradoxo fundado na separação, mas também na interligação entre sistemas autônomos, ao mesmo tempo fechados e abertos. ${ }^{43}$ Nesse caso, paradoxalmente, a clausura operacional é base para a abertura desses sistemas. É possível obter ordem do barulho e vice-versa, e nessa operação ocorre a crise do Direito oficial no momento de seu fechamento, e a dimensão emancipatória do fenômeno jurídico volta a ocorrer no momento de sua abertura. O conceito de "acoplamento estrutural" empregado por Luhmann ${ }^{44}$, num primeiro momento emprega-se ao se tratar do sistema do Direito, e do sistema da sociedade como sistemas autônomos, mas que interagem. Internamente os sistemas se autodeterminam, fecham-se em torno de suas operações próprias, suas comunicações específicas, daí se falar em termos de Direito oficial até mesmo em um vocabulário, um jargão jurídico, uma linguagem específica que traduz toda a realidade de situações e relações que as normas jurídicas são obrigadas a lidar. Entretanto, os sistemas também se desenvolvem conforme uma direção apontada por seu entorno. É o que se pode chamar aqui de irritação, moléstia ou perturbação sistêmica. Nos momentos de crise econômica ou política, sociedades presenciam a emergência de lutas, pressões e disputas com o poder político estabelecido, que podem implicar na desobediência aos imperativos normativos, como também no reconhecimento dos comandos legais, conforme o sistema do Direito oficial acopla-se ou não com seu entorno conflituoso, coalhado de grupos e movimentos que possuem orientações normativas por vezes distintas das orientações oficiais.

Impulsionados por essas irritações, muitos desses movimentos são movidos por expectativas de poder traduzidas em mecanismos de controle social ${ }^{45}$ que influenciam na tomada de decisão dos centros oficiais de poder. O pluralismo jurídico, no contexto das lutas

\footnotetext{
${ }^{43}$ Idem, p. 81.

${ }^{44}$ LUHMANN, Niklas. La sociedade de la sociedade, p. 87.

45 TEUBNER, Op. Cit., p. 88.
} 


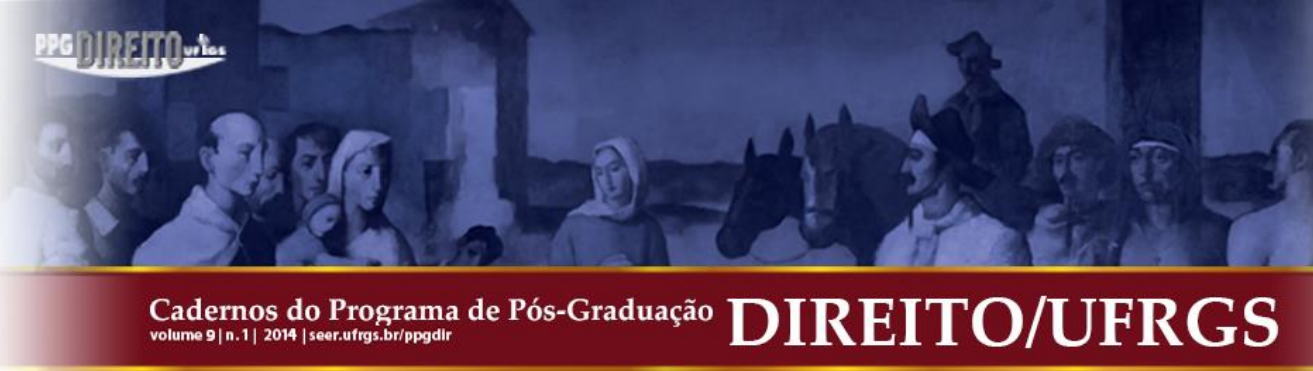

dos movimentos sociais, surge, conforme o giro linguístico seguido por Teubner, não mais como um simples corpo de normais sociais em conflito com as normas de um Direito oficial, mas sim como uma multiplicidade de processos comunicativos, orientados por um código lícito/ilícito. ${ }^{46}$ Como os súditos que se rebelam contra o soberano por não se sentirem mais representados por ele no pacto social, os manifestantes de 2013 saíram às ruas sem se inibir com o projeto criminalizante de governos locais em estigmatizá-lo como vândalos ou criminosos, colocaram suas máscaras, bandeiras e cartazes, e dispararam em passeata pelas ruas dos grandes centros urbanos do país, como que se seguindo uma norma obrigatória de cidadania, que os impulsionava a ir para os protestos, debaixo de uma curta e pitoresca frase utilizada anteriormente em campanhas publicitárias de venda de veículos, que acabou se tornando o jargão das manifestações de 2013. Sob o slogan do "Vem pra Rua!" milhares de manifestantes fizeram suas próprias normas, debaixo de bombas de gás lacrimogênio e balas de borracha lançadas pela polícia, para conter esses movimentos.

E sobre a quebra do pacto, enquanto fato gerador da resistência outrora tratada inicialmente neste texto, por meio do conservadorismo absolutista de Hobbes ou conforme o liberalismo individualista de Locke? A crise do Direito regulatório a que se refere Teubner diz respeito a certa fraqueza da comunicação no sistema do Direito oficial que, não obstante seus acoplamentos com seu entorno social, não consegue, em determinados casos, orientar normativamente as condutas de integrantes de determinados movimentos que, comportandose como manifestantes, aderem a uma lógica de protesto enquanto nova comunicação programada pelo seu próprio código de lícito/ilícito que tangencia os limites estabelecidos pelo Direito oficial. É possível ver como as expectativas normativas formadas internamente nesses movimentos reprovam, por exemplo, a violência desmedida contra terceiros, ou a destruição de um patrimônio particular que não corresponda ao patrimônio de entes estatais, alvos dos protestos. Seria equivocado afirmar, portanto, que a ação desses movimentos teria por objeto tão somente a prática de ilícitos patrimoniais e vandalismo, quando a força violenta empregada em alguma das manifestações visa muito mais despertar interlocutores para a dimensão radicalizada de uma resistência, do que a prática de ilícitos penais.

\footnotetext{
46 Teubner procura salientar que o código binário licito/típico empregado pelo sistema jurídico em sua autopoiese, como apregoa a teoria de Luhmann, não é característico unicamente do Direito oficial estatal. Tratase de uma teoria que procura negar um centralismo jurídico do Direito oficial, uma vez que não concebe nenhuma hierarquização entre esse Direito e demais manifestações jurídicas que possam partir de outros subsistemas sociais. TEUBNER, Idem, p. 89.
} 


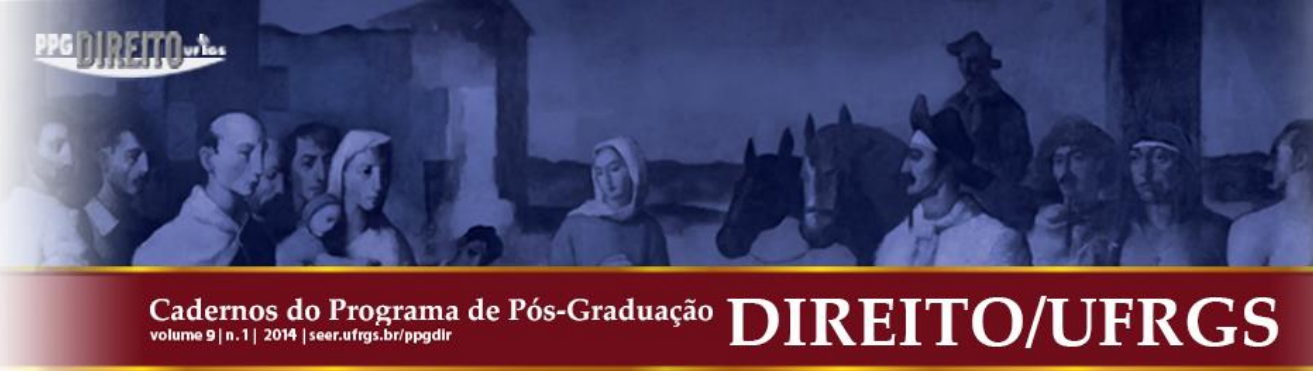

A resistência, na perspectiva do pluralismo jurídico produzido pelos movimentos sociais, implica na afirmação de novos sujeitos produtores do Direito, informando que a fonte primária do fenômeno jurídico não se encontra na vontade da autoridade ou simplesmente na razão do legislador, mas sim na dinâmica interativa da própria sociedade ${ }^{47}$. Como os movimentos sociais são agentes produtores de irritação, culminando na crise regulatória do Direito oficial, surge o momento do aprendizado, em que o sistema encontra em si próprio as causas da irritação e aprende com ela, tratando- a como uma casualidade ou normatizando-a. ${ }^{48}$ As grandes tomadas de decisão do Executivo e do Legislativo no ano de 2013, levando em conta a pressão dos movimentos sociais e o peso midiático que passou a ser configurado a essas manifestações nacionais, por meio da redução do valor de passagens, votação de temas importantes no processo legislativo, como a rejeição de um projeto de emenda constitucional que pretendia retirar o poder de investigação criminal do Ministério Público (a chamada PEC $37)^{49}$, a aprovação de um projeto de lei definindo a corrupção como crime hediondo e a redefinição das tarefas governamentais no que tange ao orçamento para a Educação e a Saúde, são exemplos cabais dos efeitos da irritação no âmbito do sistema político e do sistema jurídico.

\section{CONSIDERAÇÕES FINAIS}

Não há de se confundir o exercício de um direito com a prática de um ilícito; ao menos no que tange o tipo ideal do modelo normativo estatal, como pressuposto básico de um Direito oficial pautado na complementaridade entre regra e sanção. Entretanto, a experiência viva dos protestos de 2013 mostra que, ao contrário, o sistema do Direito oficial apresentou uma crise de regulação diante de um fenômeno social tão pitoresco quanto às manifestações sociais espontâneas, que lotaram as ruas do país a partir da metade do ano que passou.

O problema não está na aplicação da norma repressiva (como se dá no caso do Direito penal) a casos, fatos ou situações que demandam a aplicação da norma num contexto de repressão de atos tidos como ilícitos. O questionamento acerca da responsabilidade penal individual dos autores de práticas tidas como delituosas (vide os casos de violência e depredação de patrimônio) foi mais do que respondido no momento em que estes são

\footnotetext{
${ }^{47}$ WOLKMER, Op. cit., p. 151.

${ }^{48}$ LUHMANN, Idem, p. 88.

${ }^{49}$ ALEGRINI, Gabriela. Os descontentes políticos. Caros amigos. Julho de 2013, p. 27.
} 


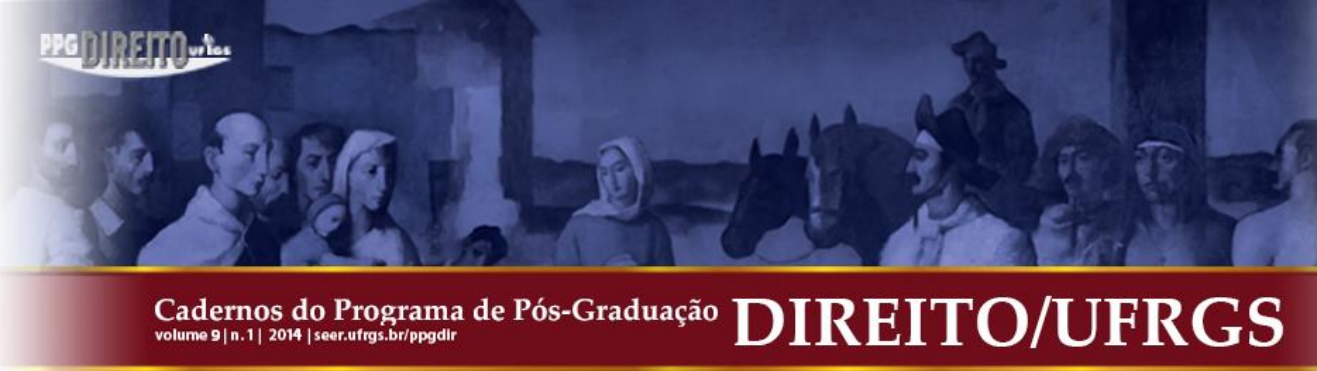

reconhecidos e sua responsabilidade é efetivamente comprovada com o emprego do devido processo legal. Assegurar, portanto, o direito de resistência e a livre manifestação de ideias não se confunde com a defesa da legalidade e a proteção jurídica de bens e interesses relevantes a uma toda uma sociedade, nos termos de um Estado Democrático de Direito, por meio do emprego do aparato repressivo estatal. Entretanto, vislumbrou-se neste estudo que a miopia ou mesmo uma cegueira institucional quanto aos limites que separam ambos os contextos, é o que mede o caráter de maturidade ou imaturidade de uma democracia, que ainda dá lentos passos em termos de uma evolução radical do modelo de Estado brasileiro observado há trinta anos, e o modelo que se encontra hoje, em pleno mundo globalizado do século XXI.

A pluralidade de novos atores políticos surgidos dos protestos de 2013 corresponde a uma pluralidade de novas possibilidades de orientações normativas, que por vezes colidem ou se tornam assimiláveis pelo Direito oficial. A resistência legalmente tolerada e a socialmente possível parecem não coincidir em certos casos, e o exemplo cabal disso deu-se na tolerância ou truculência com que os aparelhos repressivos de Estado trataram os manifestantes, no decorrer dos episódios que se multiplicaram, após os protestos iniciais pela redução das tarifas de transportes públicos, nos grandes centros urbanos.

Como o Brasil é uma democracia ainda em fase de amadurecimento, levando em conta seu passado autoritário e as sucessivas cartas constitucionais que se seguiram, até a consolidação de um novo modelo de Estado democrático, a partir da Constituição de 1988, muito ainda terá que ser visto e concebido, até que no país manifestações e protestos de rua não sejam vistos como objeto de repressão estatal pura e simples, mas sim como mais uma das formas de exercício da cidadania, dentro de um espaço público que permita o debate político, mesmo que não seja da forma legalmente prevista pelo poder político oficial.

\section{REFERÊNCIAS}

ALEGRINNI, Gabriela. O gatilho da revolta. Caros Amigos. Edição nº 196, julho de 2013.

BUZANELlO, José Carlos. Direito de resistência constitucional. Rio de Janeiro: Lumen Juris, 2006. 


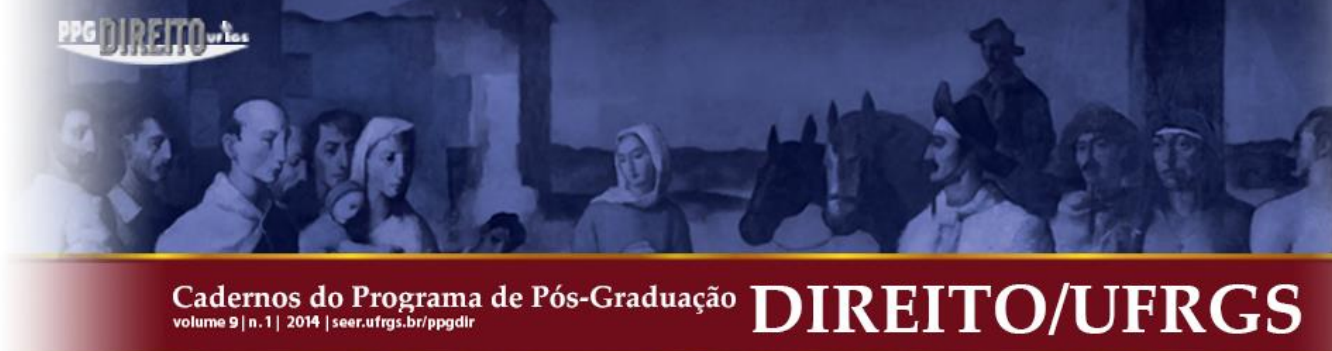

TEUBNER, Günther. Direito, sistema e policontexturalidade. Tradução Brunela Vieira de Vincenzi e outros. Piracicaba: Editora Unimep, 2005.

WOLKMER, Antonio Carlos. Pluralismo jurídico: fundamentos de uma nova cultura do direito. São Paulo: Editora Alfa Ômega, 2001.

Submissão: 20/01/2014 Aceito para Publicação: 23/05/2014 